\title{
Interactions between players in the field of pasture renewal
}

\author{
K. RIJSWIJK \\ AgResearch Ruakura, Private Bag3123, Hamilton \\ kelly.rijswijk@agresearch.co.nz
}

\begin{abstract}
The Pasture Renewal Leadership Group (PRLG) has undertaken four surveys among its members, dairy farmers, seed retailers and contractors to assess the effectiveness of the PRLG's communication around the topic of pasture renewal. This paper reviews these surveys and focusses on the interactions between the different respondent groups and the influence of the interactions on farmers' pasture renewal practices, based on the information sources each respondent group used and the credibility they attribute to them. The main information sources for farmers are farm consultants and scientists, whereas the other respondent groups mainly use their everyday contacts. Perceived credibility of the information sources by the information users, as well as the confidence level of the information user in decisionmaking about pasture renewal, influenced which information sources were used. However, consistency and clarity of the information itself remains an issue, due to competition amongst the information sources and the increased complexity of the knowledge behind pasture renewal.
\end{abstract}

Keywords: pasture renewal, communication, interaction, information sources, survey

\section{Introduction}

A survey amongst farmers was undertaken by Belgrave et al. (1990) in 1985 to find out more about their use and knowledge of pasture cultivars in New Zealand. One finding was that farmers mainly sourced information from agricultural journals, magazines and other written media. Less commonly used sources of information were advisors like seed representatives. However, even though the surveyed farmers used the media more commonly than they used the advisory group, the latter had more influence on farmers' cultivar decisions than did the media (Belgrave et al. 1990). Now, 28 years later, it is interesting to see if anything has changed in the sources of information dairy farmers use when making pasture renewal decisions.

Evidence of farmer dissatisfaction with pasture persistence and message inconsistency about pasture renewal following the droughts of 2008 and 2009 led to DairyNZ's initiative to form the Pasture Renewal Leadership Group (PRLG) in 2010. Members of the PRLG represent DairyNZ, seed retailers, AgResearch, seed companies, farmers and contractors. The purpose of the PRLG is: "To ensure consistency of messages relating to pasture renewal and provide a quality control function for those messages" (Rijswijk et al. 2013).

Surveys with dairy farmers, seed retailers, contractors and PRLG members were conducted to assess the impact of the PRLG, and to improve the PRLG's understanding of dairy farmers' practices around pasture renewal, as well as the role that the PRLG, contractors and seed retailers have in providing advice to farmers in support of their pasture renewal activities. This paper reviews these surveys to provide insight into the interactions between the different players in the pasture renewal field, and the information sources they use regarding pasture renewal, to identify how this influences pasture renewal practice.

Communication, knowledge transfer, and knowledge exchange play a role in identifying the effectiveness of these interactions and information sources. Effectiveness is shown if the outcome of the communication is a form of positive perception and practice change on the part of the farmer towards pasture renewal practice (Vaughan \& Hogg 2002).

Communication involves messages being sent from the communicator, or sender, to the audience, or receiver (Vaughan \& Hogg 2002; Jewell 1998). Effective communication occurs when the sender creates a clear and consistent message, which is sent through channels which reach the intended receiver, and is understood accurately by the receiver (Jewell 1998). In real life there will be several, maybe different or conflicting, messages sent out by different senders, through different channels, to different or the same receivers. This is where persuasion plays an important role in the communication between these different senders and receivers. Depending on the different senders' credibility, the receiver, in turn, decides which message seems to be most suitable and appropriate for their purpose or needs. The finding from the Belgrave et al. (1990) survey, mentioned above, is an example of this. The sender's credibility relies on the receiver's perceptions of the sender's expertise and trustworthiness (Myers 1990), and also includes personal aspects such as likability, status, race and attractiveness (Vaughan \& Hogg 2002; Myers 1990). Although the relationships between individuals are important in communication, 
this paper focusses on the communication between different groups and the cross group perceptions.

The type of communication that happens around pasture renewal is a form of knowledge transfer and knowledge exchange. Shaxson \& Bielak (2012) give two clear definitions of these concepts. Knowledge transfer is "a one-way process of sharing knowledge which can be construed as more of a teacher-student relationship" (Shaxson \& Bielak 2012, p.2). Knowledge exchange is "a more two-way process of sharing knowledge between different groups of people" (Shaxson \& Bielak 2012, p.2). This accords with Jewell's (1998) concepts of communication flows between groups which can be horizontal (used to influence, persuade and integrate); downward (used to command, instruct and inform); or upward (used to inform, influence and persuade). Knowledge exchange can be a form of horizontal communication flow, or vertical communication flow, including both upward and downward flows. Whereas, knowledge transfer corresponds with only a downward communication flow.

\section{Methodology}

The four different surveys were distributed by both email (with a link to an internet-based survey form) and post, and were undertaken in the Waikato and Bay of Plenty regions. The first survey with dairy farmers (mainly farm-owners) had 776 responses out of the 4246 distributed surveys (18\%). The large sample size was possible due to the availability of DairyNZ's database with farmers' contact details. The surveys with seed retailers and contractors had much smaller samples, also based on availability of contact details, often related to existing networks within the PRLG. The PRLG member survey was distributed amongst all members, 16 at the time. The latter three surveys had high response rates, e.g. the contractor survey response rate was $43 \%$ and the PRLG member survey had a response rate of $81 \%$.

The farmer, seed retailer and contractor surveys contained questions about the following elements: themselves and their work; their confidence in undertaking pasture renewal activities (or confidence in providing advice about pasture renewal); farmers' satisfaction and attitudes regarding pasture performance over time; and the information sources related to pasture renewal they used. The farmers were also questioned about their pasture renewal practices, whereas contractors and seed retailers were asked about their contact with farmers and the emerging issues around pasture renewal (Kelly \& Smith 2010; Kelly 2012; Rijswijk et al. 2013). The survey of the PRLG members had a different focus and asked about their participation, knowledge sharing, group purpose and impact, strengths, weaknesses and improvements, as well as emerging issues (Kelly \& Mackay 2012). Most surveys had a digital follow-up sent to the nonrespondents. However the contractor survey also had a phone survey follow-up due to low response rate after the two digital attempts.

The surveys included a combination of open questions and closed questions with Likert scale "tickboxes" which measured the extent to which respondents agreed or disagreed with a range of statements. The data were analysed using MS Excel, and the results (i.e., descriptive statistics) published in a series of reports (Kelly \& Smith 2010; Kelly \& Mackay 2012; Kelly 2012; Rijswijk et al. 2013). These reports were used as input for discussions by the PRLG.

\section{Results and discussion}

Comparing the confidence levels in regard to either giving advice about (seed retailers and contractors), or undertaking pasture renewal (farmers), both contractors and farmers were more confident in the practical everyday work of pasture renewal and making on-farm decisions, e.g., selecting the most suitable seed bed preparation technique and appropriate management of the renewed pastures. Contractors and farmers were less confident when it came to selecting the most suitable cultivar and endophyte for a given property (Kelly \& Smith 2010; Rijswijk et al. 2013). In contrast, the seed retailers were most confident giving advice about these latter topics which involve scientific information (Kelly 2012). Kelly (2012) pointed out that farmers and seed retailers complement each other regarding the topics in which they are confident. This complementarity in confidence was also evident between the contractors and seed retailers (Rijswijk et al. 2013).

Peoples (2011) studied the adoption practices of farmers regarding pasture renewal and the role that networks play in adoption. She found that the majority of dairy farmers $(61.8 \%)$ did not perceive contractors as a useful source of information (Peoples 2011). Because their expertise was in similar areas, the contractors only reinforced farmers' knowledge, rather than adding new information that helped farmers' decision-making. Peoples (2011) found that, with respect to pasture renewal, contractors' knowledge was not valued by farmers. Instead, farmers made use of information provided by other sources e.g., seed retailers, whom they perceived as having complementary knowledge, and therefore more credible and useful.

The information sources rated most useful by farmers were farm consultants $(69 \%$ of the respondents rated them useful or very useful) and researchers (64\% of the respondents rated them useful of which $12 \%$ rated them as very useful) (Kelly \& Smith 2010; Peoples 2011). 

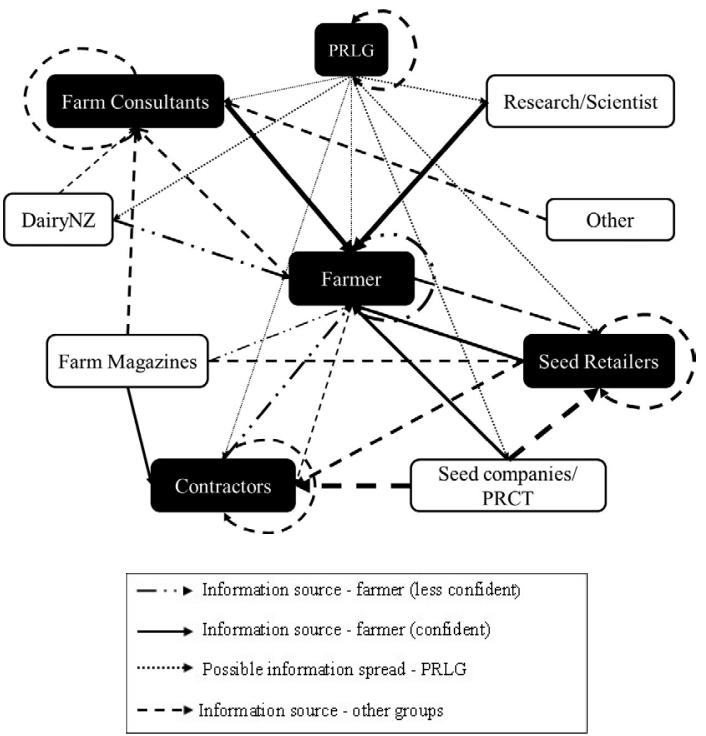

Figure 1 Information sources

Farm consultants and researchers have a high level of credibility in the eyes of the farmers (i.e., expertise and trustworthiness) and therefore are perceived as a valuable source of information. However, both farm consultants and researchers are not a frequently used information source for seed retailers and contractors (Kelly 2012; Rijswijk et al. 2013). It seems likely that contractors and seed retailers are not a target group for farm consultants or researchers in their communication, which causes an absence of communication. Moreover, the surveys show that both contractors and seed retailers use their everyday contacts as information sources, e.g., other contractors, seed retailer colleagues, farmers, seed companies or farm magazines. Figure 1 shows the main information sources used by each of the surveyed groups with the thickness of the line indicating its importance for that particular group.

Payne et al. (2010), who studied the integration of farm consultants into the DairyNZ extension network, showed that the three main information sources for farm consultants are their own experiences with farm consulting, farmer's experiences, and farm magazines, i.e., their local network (Payne et al. 2010) (Figure 1). Farm magazines are also frequently used by contractors and seed retailers as a source of information. However, these magazines were not considered that useful by farmers (Kelly 2012; Rijswijk et al. 2013; Kelly \& Smith 2010). Rather than a lack of credibility, it seems to be more likely that these magazines create a sense of awareness amongst farmers, after which they consult other information sources to receive more detailed information, which in turn could be perceived as more credible.
Farmers, seed retailers and contractors were also asked about their use of DairyNZ's personnel, website and publications as information sources in terms of pasture renewal. The farm consultants were asked the same question in a general context. None of the respondent groups used these information sources frequently, although farm consultants did appreciate the DairyNZ website. However, the farm consultants lacked confidence and trust in the DairyNZ consulting officers (COs), due to their high turnover rate (Payne et al. 2010). Again, this shows the importance of credibility. The DairyNZ website was not seen as useful by farmers (Kelly \& Smith 2010).

Farmers, contractors and seed retailers were also surveyed regarding how good they believe farmers are at accessing appropriate and useful information about pasture renewal. The access contains two aspects: the ability of farmers to search for the information as well as the availability of the information. This was regarded very positively by all three groups (Kelly \& Smith 2010; Kelly 2012; Rijswijk et al. 2013); thus accessing information appeared not to be a problem. However, despite accessibility, both knowledge and information seem to be a problem in pasture renewal and management. Contractors, seed retailers and the members of the PRLG indicated several emerging issues about the (in)capacity of farmers to make informed decisions, e.g., seed retailers mentioning that farmers need more "... awareness of doing the whole process correctly" (Kelly 2012, p.8). The PRLG identified that farmers lacked knowledge about various topics (e.g., pest and endophyte interactions) and required further training (Kelly \& Mackay 2012).

Farmers themselves did not mention knowledge and lack of information as limiting factors for pasture renewal (Kelly \& Smith 2010). They were quite confident in relation to their ability to make good pasture renewal decisions. Peoples (2011) pointed out that this could be a matter of false confidence; "Farmers who may be not aware of the latest technologies and practices and who are proceeding along with their usual pasture renewal regimes are not 'pushing the boundaries' hence not experiencing the disappointments, thus their confidence is not affected. Similarly, they may not be investing lots of time and money which lessens the losses if they occur." (Peoples 2011, p.100). According to Peoples (2011), farmers' perceptions of their efficacy in pasture renewal practice may be a limitation to further improvement in this area.

Farmer perceptions are not the only problem in relation to pasture renewal practice. The PRLG claims that a lack of consistency in the messages provided by the industry causes confusion and limits farmers' ability to make the right choices (Kelly \& Mackay 2012). 
According to seed retailers, this inconsistency in messages comes from competition within the industry to sell their own products, rather than advising the farmer about the most suitable product for their farm (Kelly 2012). The commercial focus and competition between some of the PRLG members makes it a challenge for them to reach consensus, produce consistent messages (Kelly \& Mackay 2012), and target the potential information user group (Figure 1).

Not only is there a lack of consistency, but there is also a lack of clarity in the messages. Peoples (2011) claimed that pasture renewal has become "rocket science", as farmers not only need to understand the science; they also need to know what suits their farm system. The information sources used by confident farmers and less confident farmers, regarding decision making about pasture renewal, shows the increasing complexity (Peoples 2011); less confident farmers use information sources such as contractors and fertiliser representatives, whose knowledge tends to be at a general level. Conversely, confident farmers tend to search more for professional information sources e.g., researchers or farm consultants (Peoples 2011) (Figure 1). Horizontal knowledge exchange is more important to less confident farmers, whereas confident farmers are eager to learn from people with more expertise and knowledge and rely more on upward and downward vertical communication flows.

The surveys (Kelly \& Smith 2010; Kelly 2012; Payne et al. 2010; Rijswijk et al. 2013) show that in general, farmers, seed retailers, contractors and farm consultants tend to use their everyday contacts and networks for information. Their everyday contacts are perceived as credible due to the level of trust that exists between the individuals, independently of their true level of expertise. The quality and type of interactions are influenced by the sender's credibility and the receiver's confidence. A low level of credibility negatively affects the interactions, as shown by farm consultants, for whom a lack of trust in the expertise of DairyNZ COs results in a lack of interaction between the two. The level of confidence of a group, as shown by farmers, influences the source of information valued. More confident farmers tend to go to information sources with more expertise.

Since the survey of 1985 (Belgrave et al. 1990) the perceptions and practices of the players in the pasture renewal field have changed. Moreover the field itself has become more complicated, with more knowledge and information sources required to support pasture renewal. The analysis of the surveys show that despite the efforts of the PRLG, the clarity and consistency of messages is still doubtful, partially due to competition between companies to sell their products, but also because the knowledge and science behind these messages have become increasingly complex. Thus there remain significant opportunities for the PRLG to continue to improve the effectiveness of communication around pasture renewal.

One of the opportunities is to assess the influence of farm consultants on the current pasture renewal practices and decision-making of farmers, as they are the primary source of information for farmers. Tightening the link between farm consultants and researchers would also improve the consistency of the messages towards farmers. Targeted messages to contractors and seed retailers would enhance their knowledge of pasture renewal practices, thus improve their confidence levels in both practical and scientific aspects of pasture renewal, and enable them to give better advice to farmers. For farmers, it is recommended to maintain a critical attitude towards information sources and to seek multiple sources for advice to make the best informed decision regarding pasture renewal.

\section{ACKNOWLEDGEMENTS}

The research leading to this paper was funded by New Zealand dairy farmers through DairyNZ. I would also like to thank James Turner, Bruce Small, Alasdair Craig and Grant Rennie for their useful feedback on earlier drafts.

\section{REFERENCES}

Belgrave, B.R.; Watt, P.C.; Brock, J.L.; Wewala, S.; Sedcole, J.R. 1990. A survey of farmer knowledge and use of pasture cultivars in New Zealand. New Zealand Journal of Agricultural Research 33: 199-211.

Jewell, L.N. 1998. Contemporary industrial/ organization psychology. Brooks/Cole Publishing Company, USA. 600 pp.

Kelly, S. 2012. Assessing the impact of the Pasture Renewal Leadership Group: results summary of frontline seed retailers survey. Client report prepared for DairyNZ, AgResearch.

Kelly, S.; Mackay, M. 2012. Assessing the impact of the Pasture Renewal Leadership Group: member feedback survey. Client report prepared for DairyNZ, AgResearch.

Kelly, S.; Smith, E. 2010. Pasture renewal in the Waikato and Bay of Plenty regions. Client report prepared for DairyNZ. AgResearch.

Myers, D.G. 1990. Social psychology. McGraw-Hill Publishing company, USA. 600 pp.

Payne, T.; Kelly, S.; Bewsell, D.; MacKay, M.; Roth, H. 2010. More 'reach' through farm consultants. Client report prepared for DairyNZ. AgResearch. 
Peoples, S. 2011. Perplexed pasture renewal practitioners: the perennial problem, technology adoption and the role of networks in dairy farming. Client report prepared for FRST and DairyNZ. AgResearch.

Rijswijk, K.; Ruppert, K.; Payne, T. 2013. Assessing the impact of the Pasture Renewal Leadership Group: results summary of the contractor survey. Client report prepared for DairyNZ. AgResearch.
Shaxson, L.; Bielak, A. (eds.). 2012. Expanding our understanding of $\mathrm{K}^{*}(\mathrm{KT}, \mathrm{KE}, \mathrm{KTT}, \mathrm{KMb}, \mathrm{KB}$, $\mathrm{KM}$, etc.), a concept paper emerging from the $\mathrm{K}^{*}$ conference held in Hamilton, Ontario, Canada, April 2012. United Nations University, Canada. 81 pp.

Vaughan, G.M.; Hogg, M.A. 2002. Introduction to social psychology. Pearson Education Australia, Australia. 583 pp. 
